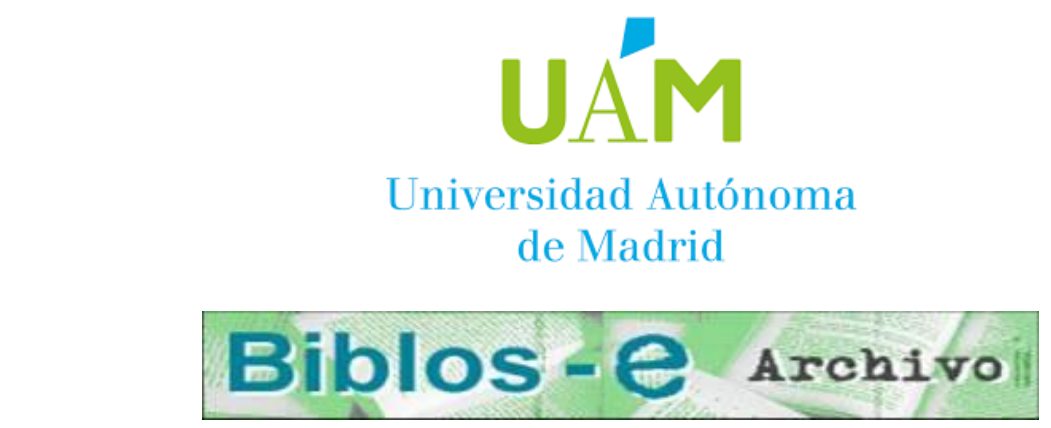

Repositorio Institucional de la Universidad Autónoma de Madrid https://repositorio.uam.es

Esta es la versión de autor del artículo publicado en:

This is an author produced version of a paper published in:

The Journal of African History 44.1 (2003): 95 - 116

DOI: https://doi.org/.10.1017/50021853702008319

Copyright: @ 2003 Cambridge University Press

El acceso a la versión del editor puede requerir la suscripción del recurso Access to the published version may require subscription 


\title{
The Decolonization of Equatorial Guinea: The Relevance of the International Factor ${ }^{1}$
}

\author{
Alicia Campos
}

ABSTRACT: The demise of Spanish colonialism in Central Africa has to be understood as part of the general process of African decolonization. In accepting the methodological framework proposed by some historians for studying the collapse of European domination in the continent, ${ }^{2}$ we can explain the independence of Equatorial Guinea, in 1968, as a result of the interaction between three different factors: international, metropolitan and colonial. This article delineates the decolonization of the only Spanish colony south of the Sahara, its main argument being that, in the case of Equatorial Guinea, the international factor - specifically, the role of the United Nations - is fundamental to the understanding of the timing, the actors' strategies and the results.

KEY WORDS: Equatorial Guinea, decolonization, nationalism.

When, as a consequence of the Spanish Civil War (1936-39), there emerged what seemed to be a new fascist regime in Southern Europe, the Western liberal powers were alarmed. None of them, however, appeared to be scandalized by that very regime's inheritance of despotic rule over several colonial populations in Africa: in the 1930s and 1940s the colonial moment was still not over, and the Spanish presence in Africa was seen as entirely normal. Among those colonies, Spanish Guinea was devoted to the yield of tropical products, mainly cocoa in Fernando Po and coffee and timber in the mainland. ${ }^{3}$ From the beginning of the

\footnotetext{
${ }^{1}$ This article is based on a $\mathrm{PhD}$ Thesis presented to the Universidad Autónoma de Madrid in September 2000, entitled Politica exterior, cambio normativo internacional y surgimiento del estado postcolonial: La Descolonización de Guinea Ecuatorial 1955-1968. (Book forthcoming). It was completed at the Centre of International Studies of the University of Cambridge and Sidney Sussex College thanks to a scholarship awarded by La Caixa-British Council during the academic year 2000-2001. I would like to thank especially Francisco Javier Peñas, James Mayall, John Iliffe, John Lonsdale, Ramon Sarró, Elissa Jobson, Lloyd Rundle and all the participants in the African History Group in Cambridge and the Grupo de Estudios Africanos in Madrid, for their kind help in producing this article.

${ }^{2}$ WM. Roger Louis and Ronald Robinson, 'The United States and the liquidation of the British Empire in Tropical Africa, 1941-1951' in Prosser Gifford and WM. Roger Louis, The Transfer of Power in Africa. Decolonisation, 1940-1960 (New Haven, 1982), 31-55; John Darwin, The End of the British Empire. The Historical Debate (Oxford, UK and Cambridge, USA, 1991); idem., 'Africa and World Politics since 1945: Theories of decolonisation', in Ngaire Woods (ed.) Explaining International Relations since 1945 (Oxford, 1996), 199-218.

${ }^{3}$ See for example, Enrique Arrojas, 'Los Territorios Españoles del Golfo de Guinea', Instituto de Estudios
} 
Franco regime, they were given a new impetus, coinciding with the 'second colonial occupation'4 in the rest of the continent. ${ }^{5}$

As in other European colonies in Africa, in Equatorial Guinea colonial society was maintained by subtle balances between many different social and ethnic groups: immigrant Nigerian workers and native peasants; the Bubi of the island and the mainland's Fang population; the rural majority and the urban Creole minority; European settlers and indigenous Africans; chiefs and subjects. ${ }^{6}$ As with the Belgian Congo, political unrest in West Africa would not reach Equatorial Guinea until the end of the 1950s. Responsibility for the colonial administration was extremely unbalanced in the Spanish dictatorial regime, centralized in the Dirección General de Marruecos y colonias (renamed the Dirección General de Plazas y Provincias Africanas in 1956), under the Minister-secretary of the Presidencia del Gobierno (Ministry of Presidency), Admiral Luis Carrero Blanco. The absence of a representative political system or strong public opinion in Spain itself assured that there was no place to debate colonial questions. However, at the end of the 1950s the Ministerio de Asuntos Exteriores (Foreign Ministry) started to take an interest in colonial policy, because of increasing international pressure on the colonial powers from the decolonization movement, which Spain could no longer ignore.

In what follows I offer some clues to understand one of the processes that have been most neglected in the literature on African decolonization. This oblivion may be due to the tiny size of the territory as well as the absence of violent conflict with international repercussions, as was the case of the Portuguese colonies. However, the study of a marginal case offers the possibility to contrast and refine 'grand theories', built around other independence processes. This article is based on United Nations, Spanish and British archives. ${ }^{7}$

Africanos, España en África (Madrid, 1948), 26-32; Instituto de Estudios Africanos, La Región Ecuatorial puesta al día (Madrid, 1963).

${ }^{4}$ D.A.Low and J.M.Londsdale, 'Introduction: towards the New Order, 1945-1963', in D.A. Low \& Alison Smith (ed.), History of East Africa, vol. III (Oxford, 1975), 12.

${ }^{5}$ Gervase Clarence-Smith, 'The impact of the Spanish Civil War and the Second World War on Portuguese and Spanish Africa', Journal of African History, 26 (1985), 309-326.

${ }^{6}$ For an analysis of the colonial system in Guinea see Alicia Campos Serrano, 'El regimen colonial franquista en el Golfo de Guinea', Revista Jurídica Universidad Autónoma de Madrid, 3 (2000), 79-108. See also Donato Ndongo Bidyogo, Historia y tragedia de Guinea Ecuatorial (Madrid, 1977); Max Liniger Goumaz, Brève Histoire de la Guinée Équatoriale (Paris, 1988); Ibrahim Sundiata, Equatorial Guinea. Colonialism, State Terror and the Search for Stability (Boulder, 1990; Gustau Nerín i Abad, La Guinea Ecuatorial, historia en blanco y negro. Hombres blancos y mujeres negras en Guinea Ecuatorial, 1843-1968 (Barcelona, 1998).

${ }^{7}$ The main sources for this work were the archives of United Nations in Geneva, the Ministerio de Asuntos Exteriores in Madrid (AMAE), the Archivo General de la Administración in Alcalá de Henares (AGA); the archive of the Congreso de los Diputados in Madrid (ACD); the Filmoteca Nacional in Madrid and the 


\section{THE INTERNATIONAL ARENA}

The first anti-colonial demands from the international arena were felt with the admission of Spain into the United Nations in December 1955, along with another 15 states, as a result of an agreement between the world superpowers. ${ }^{8}$ The Cold War had made Franco's Spain, previously excluded from the UN because of the support that she had received from Hitler, ${ }^{9}$ an essential asset in the United States strategy against the Soviet Union. For its part, the Spanish Foreign Ministry had devoted all its efforts to overcoming international isolation, preserving Franco's personal rule, ${ }^{10}$ for which foreign affairs officials had tried to build strong diplomatic relations, not only with the United States, the Vatican and Portugal, ${ }^{11}$ but also with Latin American and Arab countries. ${ }^{12}$ These last relationships would have important consequences for the attitudes adopted by the Spanish government towards African decolonization.

As soon as they joined the United Nations, in a context of growing anti-colonial anxiety, new members were promptly questioned about their colonies. Concretely, the Secretary-General requested them to observe Article $73 \mathrm{e}$ of the Charter, ${ }^{13}$ which obliged colonial powers to supply information 'relating to economic, social and educational conditions in the territories for which they

Hemeroteca Nacional in Madrid, as well as interviews conducted in Equatorial Guinea (August 1999) and Madrid (November 1999). The Proceedings of the Constitutional Conference of Equatorial Guinea, 19671968, are not currently accessible in the public archives at the present, but they could be consulted thanks to private libraries. Further archive research was carried at the Public Record Office in London (PRO).

${ }^{8}$ General Assembly Resolution 995(X), of 14 Dec. 1955.

9 Florentino Portero, Franco aislado: la cuestión española 1945-1950 (Madrid, 1989); Alberto LleONART AMSÉlem, 'El ingreso de España en la ONU: obstáculos e impulsos', Cuaderno de Historia Contemporánea, 17 (1995), 101-119; idem., España y la ONU: La 'crisis española' (Madrid, 1978, 1996).

${ }^{10}$ On the aims of Franco's foreign policy see Francisco Aldecoa, 'Las constantes de la política exterior española', Política y Sociedad (Winter 1989), 61-78; Ángel Viñas, 'La política exterior del franquismo', in Juan Bautista Vilar, Las relaciones en la España contemporánea (Murcia, 1989), 115-124; Florentino Portero y Rosa Pardo, 'La política exterior', in Historia de España. Menéndez Pidal vol. XLI: La época de Franco (1939-1975). Política, Ejército, Iglesia, Economía y Administración (Madrid, 1996), 193-299; Pedro Antonio Martínez Lillo, 'La Política Exterior de España en el marco de la Guerra Fría: del aislamiento limitado a la integración parcial en la sociedad internacional (1945-1953)', in Javier Tusell, Juan Avilés and Rosa Pardo (eds.), La Politica Exterior de España en el Siglo XX (Madrid, 2000), 323-341.

${ }^{11}$ In 1953 the Spanish government signed a number of international agreements which became essential instruments of the process of Spain's reintegration in international society: the economic and military pacts with the United States, and a concordat with the Vatican. Luso-Spanish relations were established from the beginning of the Franco regime, which was cemented by a treaty of friendship and non-aggression made in March 1939.

${ }^{12}$ Many scholars have considered these latter relations as 'politics of substitution' of Franco's foreign policy. See Fernando Morán, Una política exterior para España (Barcelona, 1980). 
are respectively responsible'. ${ }^{14}$ This was the only mechanism available to the emergent anti-colonial movement at the international level. It took more than two years for the government in Madrid to decide its response to the demands of Article 73e. The reply to the Secretary-General's request was an issue of debate between those in charge of the colonial administration, in the Ministry of Presidency, and the Foreign Ministry officials, headed by Fernando M. Castiella after 1957. The former argued against admitting to possessing colonies, since that would be to accept the temporary character of the Spanish presence in Africa and to acknowledge international competence on Spanish internal affairs. ${ }^{15}$ In contrast, the Foreign Ministry put forward a strong case for delivering the information demanded by New York, fearing that, otherwise, Spain would once again be excluded from the international mainstream and alienate the Latin American and Arab states, whose hard-won support had been instrumental to Spanish admission to the UN. ${ }^{16}$

The final decision took the form of the Presidency's proposal, which was inspired by the Portuguese reaction. ${ }^{17}$ Portugal had denied the existence of colonial populations under its sovereignty, claiming that the African territories were part of the national territory and, therefore, covered by the international principle of non-intervention. ${ }^{18}$ In order for this assessment to seem plausible, a change in the colonial legislation, known as provincialización, was initiated, aimed at the integration of Spanish Guinea into the administrative territorial structure of the metropolitan state. From 1959, the two main parts of the colony -the island of Fernando Po and the mainlandwere reclassified as the Spanish provinces of Fernando Po and Rio Muni. ${ }^{19}$ Actually, little more than the name was changed, and the colonial system of domination remained almost untouched, except for an increased africanization of the administration. ${ }^{20}$

\footnotetext{
${ }^{13} \mathrm{UN}$ A/C.4/331, Note by Secretary-General (letter of 24 Feb. 1956).

14 The information obtained was debated in the Committee on Information from Non-Self-Governing Territories, set up to that end.

${ }^{15}$ Report 'Escrito reservado n.4127 de la D.G. de Marruecos y Colonias', of 19 May 1956, AMAE R.5071/16; Letter n.667 from director general de Plazas y Provincias Africanas to subsecretario Ministry of Foreign Affairs, of 9 Nov. 1956, AMAE R.5071/17; Report 'Réplica a las observaciones que formula el Ministerio de Asuntos Exteriores al Anteproyecto de ley de bases sobre reorganización de los territorios españoles de Guinea', of 28 Jan. 1958, AGA 479/1.

16 Report 'Informe relativo a la información a las Naciones Unidas sobre territorios no autónomos, artículo 73 de la Carta' of 1 June 1956, AMAE R.5071/16; Report 'Informe sobre las consecuencias que produciría en las Naciones Unidas la negativa a enviar información sobre los territorios españoles de Guinea', of 20 Jan. 1958, AMAE R.5072/28.

17 The Spanish government wrote to the UN Secretary-General at the end of 1958 denying possession of non-autonomous territories. Communication of 10 Nov. 1958 from Permanent Mission of Spain, UN A/C.4/385/Rev.1.

${ }^{18}$ Statement of Representative of Portugal on 30 Jan. 1957, UN A/C.4/347.

${ }^{19}$ Ley 191/1959 de Bases sobre organización y regimen jurídico de las provincias africanas.

${ }^{20}$ New local institutions, Ayuntamientos (town councils) and Diputaciones Provinciales (county councils),
} 
The assimilationist reform created critics inside and outside the colony. In Guinea, it stimulated the growth of the nationalist movement, as we will see, whilst in Spain it provoked objections among those officials who had to defend the new colonial policy within the supranational organizations. The atmosphere in the United Nations persuaded Spanish diplomats that trying to avoid international control of the colonial question, thereby following the Portuguese path, could bring unforeseen and unpleasant consequences. ${ }^{21}$

As was to be expected, the pressures on Portugal and Spain did not cease, and peaked in 1960, when many African territories became independent states, including all of Spanish Guinea's neighbours: Nigeria, Cameroon and Gabon. In December the General Assembly of the United Nations passed a majority resolution, $1514(\mathrm{XV})$, on the Declaration on the Granting of Independence to Colonial Countries and Peoples. This resolution brought about a new interpretation of the international principle of self-determination according to which colonial tension could only be resolved by transferring sovereignty to the territories previously defined by the European overseas expansion. ${ }^{22}$ At that time, another text was drafted which aimed to condemn the unyielding stance of Portugal and Spain, listing each of their colonies and requiring them to transmit information in accordance with Article $73 \mathrm{e}^{23}$

Spanish diplomats desperately attempted to avoid this direct international disapproval. At the same time some of the delegations of the anti-colonial bloc, in particular some Latin American states and India, preferred to see Spain gently pushed towards the path of decolonization rather than violently condemned. Hence, after informal conversations with a number of the sponsors of the draft resolution, the head of the Spanish delegation, José Félix de Lequerica, made a statement before the Fourth Committee of the General Assembly, in which he stated that the Spanish

were set up. They had few responsibilities and little budget, but more and more Africans would participate in them over the years. Under the new legislation, both provinces sent procuradores (representatives) to the Francoist Cortes (legislative assembly) for the first time in 1960, three of them Africans. However, the dictatorial character of the Spanish regime distorted the democratic dimension of this reform.

${ }^{21}$ Letter from Subdirección de Naciones Unidas to director general de Marruecos y Colonias of 17 July 1956, AMAE R.5071/17; Report of the Subdirección de Naciones Unidas 'relativo a la información sobre territorios no autónomos' of 27 Oct. 1956, AMAE R.5071/17; Letter of the Subdirección de Naciones Unidas a la D.G. de Plazas y Provincias Africanas of 3 Nov. 1956, AMAE R.5072/16; Telegram n.176 from the permanent representative in UN, José Félix de Lequerica of 30 Oct. 1956, AMAE R.5071/16.

${ }^{22}$ See for example Yassin El-Ayouty, The United Nations and Decolonisation. The Role of Afro-Asia (Nijhoff, The Hague, 1971); M. Pomerance, Self Determination in Law and Practice. The New Doctrine in United Nations (The Hague, 1982); Lynn Berat, Walvis Bay, Decolonisation and International Law (New Haven \& London, 1990); Antonio Cassese, Self-determination of People. A legal reappraisal (Cambridge, 1995); Antonio Remiro Brotons, 'La libre determinación de los pueblos coloniales', in A. Remiro et al., Derecho Internacional (Madrid, 1997), 110-137.

${ }^{23}$ UN A/C.4/L.649, 8 Nov. 1960. 
Government had decided to transmit the required information. ${ }^{24}$ The move took effect immediately, and any condemnation of Spain was removed from the resolution, which was finally approved, leaving Portugal isolated. ${ }^{25}$ The peculiarity of the Spanish promise was the absence of additional instructions from Madrid modifying the government stance towards the colonial question. It was entirely a decision made by the Spanish diplomats in New York in the face of the growing anticolonial movement in United Nations.

Madrid's first reaction was to reject and condemn its diplomats' action. ${ }^{26}$ It went so far as to offer the resignation of the Spanish delegation in New York by way of apology to the Portuguese government - though the offer was not accepted. ${ }^{27}$ Spanish officials in the Foreign Ministry were well aware of the dangers of participating in the international organisations on colonialism and using the language prevailing there: 'Whatever the motives of our delegation, there is no doubt that we now find ourselves with little room for movement inside the United Nations' conceptual world, in relation to this subject'. ${ }^{28}$

However, pressures from the delegates themselves, ${ }^{29}$ along with an expression of concern from the United States, ${ }^{30}$ made the Spanish government accept the compromise already made in the United Nations. The following year, in spite of strong resistance from the colonial administration, Spain submitted information on its African colonies to the Committee on Information. ${ }^{31}$ And the Minister-secretary Carrero Blanco himself, during a visit to the colony that year, stated that the government would not oppose changing the status of both 'Provinces' on the basis of self-determination, though it would only do so when the population was well prepared. ${ }^{32}$ Events in the international arena, mainly the United Nations, were constraining and changing

\footnotetext{
${ }^{24} \mathrm{UN}$ A/C.4/SR. 1048.

25 General Assembly Resolution 1542(XV) of 15 Dec. 1960.

${ }^{26}$ Note of the Dirección General(D.G.) de Politica Exterior (Subdirección de Asuntos Políticos de Africa), 'Desarrollo Cuarta Comisión resolución sobre España' of 11 Nov. 1960, AMAE R.8786/1; Telegram n.145 from the Minister to the Spanish delegation in UN of 11 Nov. 1960, quoted in Note of the D.G. Politica Exterior (S.A.P.Africa) 'Información de Prensa sobre proyecto de resolución votado en Cuarta Comisión de Naciones Unidas. Referencias a la actitud española' of 24 Nov. 1960, AMAE R.8786/1; Report of the D.G. Politica Exterior of 24 Nov. 1960, AMAE R.8786/1.

${ }^{27}$ Jaime de Piniés, La descolonización del Sáhara: un tema sin concluir (Madrid, 1990), 15.

${ }^{28}$ Report of D.G. Politica Exterior of 24 Nov. 1960, AMAE R.8786/1.

${ }^{29}$ Letter n.495 of Jaime de Piniés of 13 March 1961, AMAE R.5623/24.

${ }^{30}$ Note from D.G. de Organismos Internacionales to the Minister of 11 April 1961, AMAE R.8786/2.

${ }^{31} \mathrm{UN}$ A/4785, Report of Committee of Information with verbal intervention of Jaime de Piniés.

32 Discourse of Carrero Blanco at Santa Isabel on 19 Oct. 1962, Diario ABC 21 Sep. 1962. Despite the ambiguity of the statement, it was frequently quoted at the United Nations by the Spanish delegation as a proof of the change of attitude in Madrid. Statement of Lequerica in the General Assembly, 17 Nov. 1962, UN A/PV.1177.
} 
Spanish discourse towards its colonies. ${ }^{33}$

\section{THE ANTI-COLONIAL NATIONALIST MOVEMENT IN SPANISH GUINEA}

The policy of Provincialisation in the late 1950s enhanced political awareness among the colonial population in Guinea. In spite of partial africanization of the administration, it was the African elite, comprising the Creole population of the island, civil servants, employees of European firms, small landowners and chiefs, which suffered most from the contradiction between the assimilationist discourse and the reality of discrimination. It was in these years that political dissidence began to take shape within the African elite. Its initial weakness among the population would only be overcome with a resort to external support, exemplifying the strategies of extraversion described by J.F. Bayart as one of the main features of African politics. ${ }^{34}$

The late development and relative weakness of African nationalism in Spanish Guinea, when compared with other African colonies, can be explained by a number of factors. First, the relative isolation of Guinea, as the only Spanish colony in Sub-Saharan Africa, was aggravated by the dictatorial character of the metropolitan state, which made the articulation of political demands of any kind more difficult than in colonies ruled by more liberal powers. Indeed, repression was the main reaction of the Franco regime towards any call for change. ${ }^{35}$ However, from the beginning of the 1960s, the growing awareness of hostile international opinion towards the continuation of colonialism turned Spain's initial reaction into a policy of appeasement. ${ }^{36}$

Second, the social group that suffered most under the colonial regime were the West

${ }^{33}$ Spain also came under pressure from the Economic Commission for Africa, which approved a resolution in 1962, 43(IV), condemning Portugal and Spain for not having native inhabitants as representatives of their African territories. The year after, Spain africanized its delegation to the ECA. Spanish Guinea was also considered at the Conference of the African and Malgache Union in Libreville, in 1962, whose final communiqué expressed concern about Spanish colonialism.

34 Jean François Bayart, The State in Africa: The Politics of the Belly (London, 1993).

35 For example the violent reaction in 1959, against the expressions of discontent towards the provincialización process, including the non-clarified death of the landowner Acacio Mañe, who became one of the nationalist symbols of Equatorial Guinea. Donato Ndongo, 'España y Guinea (1958-1968)', Historia 16, Special Edition (1983), 107-128; René Pelissier, 'Uncertainties in Spanish Guinea', Africa Report (March 1968), 16-38.

36 'This Gobierno General, though under intense pressure, has unlimited patience and is not ready to play along with them [the nationalists], especially during the meetings of the [UN] General Assembly, and is therefore vigilant and is discretely controlling them, and not only does not provide them with martyrs and corpses, but is helping those who, disappointed, are trying to return to their homes in our region, from Cameroon or Gabon'. Report from the Governor-General n.980-S of 29 Oct. 1962, AMAE R.7014/45. 
African workers of the cocoa plantations in Fernando Po, who, as foreigners alienated from the rest of the Guinean population and subjected to special legislation, were not prone to express their discontent openly. ${ }^{37}$ The large number of Nigerians living in Fernando $\mathrm{Po}^{38}$ led some trade unions in Lagos to express Nigerian territorial claims over the island. ${ }^{39}$ However the Nigerians' most important role was to release the Guinean people from the hardest work in plantations and public infrastructures, as well as to bring in news of social unrest and political change in West Africa.

The first organized movements demanding the independence of the colony were thus developed in association with exiles living in Gabon and Cameroon at the beginning of the 1960s. One group based in Ambam, Idea Popular de Guinea Ecuatorial (IPGE), cultivated strong relations with the government in Yaounde, and went as far as to sketch the future unification of Equatorial Guinea and Cameroon. ${ }^{40}$ Other important groups sprang up in Gabon, around exiles such as Atanasio Ndong and Bonifacio Ondó Edú. The former became external representative of the Movimiento Nacional de Liberación de Guinea Ecuatorial (MONALIGE), ${ }^{41}$ whereas the Unión Popular de Liberación de Guinea Ecuatorial (UPLGE) was created by Ondó Edú in Libreville, backed by the government of Leon Mba. The internal social bases of these groups were in part regionally determined: IPGE and UPLGE maintained connections with the Fang population in the northeast and southwest region of Rio Muni respectively. MONALIGE, whose core supporters were the colony's petit-bourgeoisie, had a more diverse ethnic composition, including Creole businessmen, the ruling Bubi chiefs and educated Fang from the mainland. Its headquarters were in Santa Isabel, with local branches spread all along the mainland coastal area. One of the main tensions among the emergent nationalists was around the idea of collaboration between those who participated in the colonial administration and those who wanted to break with it. Although

\footnotetext{
37 The problem of labour shortages in Fernando Po's plantations led to the employment of a large number of immigrants from other parts of West Africa, in particular Nigeria through an agreement between the Spanish government and the British colonial authorities The first agreement was signed on 9 Dec. 1942. Boletín Oficial de las Cortes of 1 Feb. 1943.

38 The 1960 census indicates that there were more than 40.000 Nigerians in Fernando Po out of 72.230 inhabitants. Letter of Gobernor-Gereral on 17 March 1962 'Censo mejorado de 1960 de los Servicios de Estadística, Policía Trabajo y A.S.E.A.', AGA, 794.

${ }^{39}$ Max Liniger Goumaz, Brève Histoire de la Guinée Équatoriale (Paris, 1988).

${ }^{40}$ Early members of IPGE were Enrique Nvó, Clemente Ateba, José Perea Epota, Antonino Eworo and Jaime Nseng. UN A/AC.109/SR.447; UN A/AC.109/PET.500/Add.1; Ndongo, 'España y Guinea' .

${ }^{41}$ Early leaders of MONALIGE were Abilio Balboa Arkins, Pastor Torao Sikara, Francisco Dougan Mendo, Felipe Njoli, Agustín Eñeso, Esteban Nsue, Ángel Masié, Justino Mbá. Proceedings of meeting of Consejo Superior del MONALIGE, Santa Isabel, 12 September 1963, according to Note from the GovernorGeneral n.125, of 17 Sep. 1963, AMAE R.7016/5. See also UN A/C.4/SR.1412 and 1413.
} 
attempts to reach to coalitions were sometimes made, ${ }^{42}$ fragmentation was a main feature of the Guinean nationalism. ${ }^{43}$

The difficulty of these groups was to make use of a discourse of liberation understandable by the metropolitan power, as had been the case in the British and French colonies and had given the African nationalists a most powerful tool against the colonial system ${ }^{44}$. The anti-liberal character of the Francoist regime reinforced the despotism of the colonial administration, which could not conceive of the articulation of political or social demands in any associational form. Only the idea of nation, so central to Franco legitimation, and the precedent of Spanish America independence, could offer concepts with which to imagine the end of Spanish colonialism in Guinea. But it was mainly others' experience in Africa that provided the imaginary of a future independence to Guinean nationalists. There emerged thus a double language for the part of the Guinean activists at the time: one based on the 'autodeterminación' (self-determination) and the illegality of colonialism, that was used mainly abroad; another, used in the interior of the colony, that presented the future independence as the culmination of the civilizing project of the Spaniards and highlighted values such as order and discipline. In general, the anti-colonial struggle in Equatorial Guinea lacked the elaboration it showed in Portuguese Africa.

Throughout the 1960s militants from these groups appeared not only in Gabon and Cameroon, but also in Ghana, Guinea, Nigeria, Algeria, Congo-Brazzaville and the United Arab Republic. ${ }^{45}$ Nevertheless, it was the United Nations' headquarters in New York that proved to be the most fruitful of these international links. Those who could address the United Nation were able to overcome the internal weakness of their movement as well as the indifference of the Spanish colonial authorities: Spain turned out to be much more receptive within the international organization, where it had to adopt a more liberal discourse than the one used at home. The first petitioners from Spanish Guinea were heard at the General Assembly's Fourth Committee in December 1962, where they denounced the strategy of assimilation the Spanish government was

\footnotetext{
42 This was the case of the Oficina de Coordinación de los Movimientos Guineanos (Co-ordination Bureau of Guinean Movements) between MONALIGE and IPGE, in 1963 in Cameroun. René Pelissier, 'Le mouvement nationaliste en Afrique espagnole', Le mois en Afrique (July 1966), 82-83.

${ }^{43}$ The observation made by Tony Smith is totally applicable to Equatorial Guinea: 'there are a variety of nationalist movements behind what to the casual observer, may seem like a single wave of nationalism, and these diverse groups frequently are seriously at odds'. Tony Smith, 'Patterns in the Transfer of Power: A Comparative Study of French and British Decolonisation', Gifford \& Louis (eds.), The Transfer of Power, 108.

${ }^{44}$ Frederick Cooper, Decolonization and African society (Cambridge, 1996)

${ }^{45}$ They spoke on behalf of MONALIGE and IPGE, and even, as was the case of Luis Maho, under another name (the Mouvement pour l'independence de la Guinea Ecuatorial) without any real social base. UN A/AC.109/PET.500/Add.1; UN A/AC.109/PET.529.
} 
carrying out without consulting the population, and asked for independence. As was to be expected, they found strong support among the African delegations, especially Cameroon and Gabon. ${ }^{46}$ Not only did the nationalists make use of United Nations, but some of the most important collaborators with the colonial administration also appeared as part of the Spanish delegation: Wilwardo Jones Niger, mayor of Santa Isabel, participated in the Committee of Information and in the General Assembly in $1962 .{ }^{47}$ However, the presence of Guinean petitioners claiming independence made the Spanish defence of the assimilation process even less credible.

\section{THE REGIME OF AUTONOMY OF EQUATORIAL GUINEA}

To counter internal and international pressures, the Spanish government decided to carry out new legislative reform in Guinea, spearheaded this time by the Foreign Ministry and not by the Ministry of Presidency. ${ }^{48}$ Now the model would not be Portuguese integration but rather, a compromise between the late colonial policies of Britain and France, which involved administrative decentralization and the establishment of an autonomous government in Guinea. At the same time, an economic program, the Economic Development Plan for the Equatorial Region, was passed as part of the general economic development plan for Spain, its express aim being to raise public investments in the territory, especially for social expenditure and infrastructure. ${ }^{49}$

The Regimen de Autonomía de Guinea Ecuatorial was intended in the mind of its makers to comply with the international principle of self-determination and to attract the nationalist elite towards the colonial government. In fact, the new legislation, which combined and renamed the two former 'provinces' as Equatorial Guinea, superimposed some quasi-representative bodies on top of the old colonial institutions. Along with the old Governor-General, renamed Comisario General (High Commissioner), a pseudo-legislative council (Asamblea General) and a governing

\footnotetext{
46 Statement of Atanasio Ndong, on 6 Dec. 1962, UN A/C.4/SR.1412 and 1413; Statements of Luis Maho and José Perea Epota, on 12 Dec. 1962, UN A/C.4/SR.1420.

${ }^{47}$ Circular of 7 May 1963, AMAE R.7330/44; Letter of D.G. de Plazas y Provincias Africanas of 3 Nov. 1962, AMAE R.8745/3.

${ }^{48}$ It originated from a proposal put forward by Jaime de Piniés, the Spanish assistant permanent representative in New York: Report of Jaime de Piniés 'La cuestión colonialista', of 24 May 1963, AMAE R.7016/7.

49 The total amount of investment for the following four years was expected to reach 1,651 million pesetas. Report 'Documento revisado de la Comisión para el Desarrollo Económico de la Región Ecuatorial', Comisaría del Plan de Desarrollo Económico, Oct. 1963, AMAE R.8048/11.
} 
council (Consejo de Gobierno) were put in place. ${ }^{50}$ The indirect and corporate character of the Spanish franchise diminished the representative capacity of these bodies and the retention of essential powers in the High Commissioner's hands became a source of conflict and complaint among the African elite. The Autonomy could not avoid suffering from the dictatorial character of the colonial power, which was trying to 'play at democracy' in the colony without knowing or applying the rules at home.

Nevertheless, this new political arrangement included important changes, mostly a significant rise in African political awareness and participation in the colonial administration. After a pseudo-democratic process, including a referendum among the colonial population, the Regime of Autonomy was approved at the end of $1963 .{ }^{51}$ During the referendum campaign, political groups were allowed, for the first time, publicly to express their views as such. Most of them, with the exception of the majority of IPGE $^{52}$ and the island branch of MONALIGE, gave their support to the new regime, considering it to be a preliminary step towards independence. ${ }^{53}$ The different voting behaviour in Fernando Poo than in the mainland is mainly explained by the odd concurrence of white minority vote, contrary to any change in the colonial system, and the campaign of MONALIGE in the island, in favour of a more radical transformation. Also during this time, many of the exiles in Gabon and Cameroon came back to Guinea to take part in the process, although MONALIGE decided that its Secretary-General, Atanasio Ndong, would remain in exile. ${ }^{54}$

At the beginning of 1964, the new regime came into effect through indirect elections. The former exile Bonifacio Ondó Edú became the President of the Governing Council and headed a new semi-official political group, the Movimiento de Unidad Nacional de Guinea Ecuatorial (MUNGE) that attempted to draw together the most moderate of the nationalists and the old colonial collaborators. This new movement was encouraged by the Spanish colonial government as a way of finding new collaborators among the moderate opposition, whilst taming African nationalism. Rising investment in the new institutions enhanced the dependence of the political elite

\footnotetext{
${ }^{50}$ Ley de bases del Regimen Autónomo de Guinea Ecuatorial, 191/1963.

${ }^{51}$ Results of the referendum on 15 December, according to the data offered by the Spanish government to United Nations, were 59,280 votes in favor against 35,537 votes against (5,340 in favour vs. 7,150 against in Fernando Po). UN A/5800/Rev.1.

${ }^{52}$ A group detached from IPGE and headed by Jaime Nseng, the Movimiento Nacional de Unión (National Union Movement), campaigned for the Regime of Autonomy.

${ }^{53}$ UN A/5800/Rev.1.

54 UN A/AC.109/PET.245; Note of D.G. de Plazas y Provincias Africanas to D.G. Organismos Internacionales of 22 Nov. 1963, AMAE R.7016/5.
} 
on the metropolitan powers and generated a timid politics of the belly. The result was that those who participated in the Regime of Autonomy gained an interest in the continuity of the political and economic arrangement with Spain.

However not all the nationalists were co-opted by the colonial regime. The limits to the representation and executive capacity of the new institutions, along with the greater freedom of movement tacitly allowed to political groups, helped to promote open confrontation within the nationalist movement. The Autonomy redrew the line that divided those nationalists prone to collaborate with the Spanish authorities and those who preferred to remain unconstrained. MONALIGE, despite its initial support of the new regime during the referendum, soon became its most furious critic, as well as the strongest social movement in the territory, with an important network of local committees. It avoided cooptation by the colonial authorities in part by maintaining its secretary-general in exile. While MONALIGE was consolidated, IPGE lost some of its ascendancy, partly because its call for unification with Cameroon did not find local support. ${ }^{55}$

During this time, another group, more informally organized, emerged, provoking another split among the nationalists. Based in the island, it had support among the small Guinean petitbourgeoisie and the Spanish settler community, which, in the name of the Bubi population, started to articulate its desire for independence from the mainland. One of its aims was to maintain the special economic relationship with the metropole, mainly based on cocoa production. Some of its leaders were veteran nationalists and members of the autonomous institutions from the island, which created a situation of division and confrontation in the Governing Council. ${ }^{56}$

But perhaps the most important development in the politics of Ecuatorial Guinea throughout the Regime of Autonomy was the radicalisation of the members of the official group, MUNGE ${ }^{57}$ Following this, there was an attempt to unite with the leaders of IPGE who had returned from exile. ${ }^{58}$ And most importantly, MUNGE's sympathizers in the Asamblea General joined those close to MONALIGE in a censure motion against the Governing Council. ${ }^{59}$ Though

\footnotetext{
55 Between Oct. 1964-March 1965 the exiled leaders of MONALIGE and IPGE formed a short-lived unification under the name of Frente de Liberación Popular de Guinea Ecuatorial (FRENAPO). UN A/AC.109/PET.358 and Add.1; UN A/AC.109/SR.447.

${ }^{56}$ These leaders were Enrique Gori Molubela, president of the Diputación Provincial in Fernando Po, Aurelio Nicolás Itoha, Gustavo Watson Bueko, Román Boricó Toichoa and Luis Maho Sicacha, members of the Governing Council. Report of Subcommittee of Equatorial Guinea, III, UN A/6300/Rev.1, Chapter IX.

${ }^{57}$ René Pelissier, 'Le mouvement nationaliste en Afrique espagnole', Le mois en Afrique (July 1966), 7296.

${ }^{58}$ Report of Subcommittee of E.G., III.D, UN A/6300/Rev.1, Chapter IX.

${ }^{59} \mathrm{UN}$ A/AC.109/PET.500/Add.1; UN A/AC.109/PET.529. It is worth noting here that representation in the General Assembly was not based on political parties, but on corporate representation, though most of the
} 
this action did not have its intended effect, the Governing Council was re-shuffled and as a result a new High Commissioner was appointed from Madrid. ${ }^{60}$ General dissatisfaction with the regime was displayed in the strike of civil servants between 21 and 23 April 1966. ${ }^{61}$ It was clear that, by that time, the Regime of Autonomy was not satisfying any social or political group. While the differences in the Guinean society had increased during this period - between the governing African elite and the rest of the population, between different political groups, or between elders and youth - due to the different access to the resources of power, independence became the horizon of almost everybody, and social conflict was now expressed, invariably, in its language.

\section{THE UN SPECIAL COMMITTEE OF TWENTY-FOUR}

From 1963, the case of Equatorial Guinea was considered at the meetings of the Special Committee of Twenty-four, established the year before to monitor the implementation of Resolution $1514(\mathrm{XV}){ }^{62}$ The Spanish authority strove to validate their statement that the people of the territory were now enjoying self-determination through conceded autonomy and that it was now for the people of Guinea to decide their own future. ${ }^{63}$ But it did not convince the Committee, nor did it prevent it from passing resolutions, from 1964 onwards, demanding a further step: the full independence of Equatorial Guinea. There were two main obstacles to the acceptance of the Spanish policy of Autonomy. One was its dubious democratic character. Second, in the middle of the 1960 s, self-determination was only understood to mean sovereign independence - no result other than statehood for colonial populations now satisfied the United Nations.

The relationship between the Spanish delegation and the anti-colonial group at the UN was one of extraordinary ambivalence. The majority of the delegations from Latin America were ready to support Spain in its efforts to present itself as a reasonable colonial power. At the other extreme, Soviet delegations were prone to use the Spanish presence in Africa to attack the Franco regime. In the middle, the African representatives' main concern was with the implementation of resolution

\footnotetext{
members were sympathisers with one or other nationalist group.

${ }^{60}$ Víctor Suances del Río replaced Faustino Ruiz González in 12 August 1966. Pelissier, 'Le mouvement', 95-96.

${ }^{61}$ UN A/AC.109/PET.529; Report of Subcommittee of E.G. III.C, UN A/6300/Rev.1, Chapter IX.

${ }^{62}$ The resolution 1654(XVI) of 27 Nov. 1961, established the Special Committee on the Situation with regard to the Implementation of the Declaration on the Granting of Independence to Colonial Countries and Peoples. See also Maurice Barbier, Le Comité de Décolonisation des Nations Unies (Paris, 1974).
} 
1514(XV) and the attainment of independence for all of the remaining colonies. Nevertheless, their strategies varied from open confrontation with Portugal to the gentle persuasion of Spain. The latter's interest in African support for its claim on Gibraltar was used as additional leverage by the African Group in its demands for a more flexible attitude from Spain. ${ }^{64}$ The most radical delegations were countries such as Ghana and Guinea, and the neighbouring states of Cameroon and Gabon, although initial critical statements from these last two countries about Spanish colonialism in Equatorial Guinea softened in tone after the approval of the Regime of Autonomy and the return of refugees. The African states also made use of other forums such as the Organization of African Unity to demand the independence of Equatorial Guinea, but the tone and kind of pressures exerted against Spain were extremely mild in comparison to those used against Portugal or South Africa. ${ }^{65}$

The Committee of Twenty-four adopted the first resolution on Equatorial Guinea in October 1964, requesting the establishment, at the earliest possible date, of its independence following consultation with the people on the basis of universal suffrage under the supervision of the United Nations. ${ }^{66}$ In December 1965, a similar text was approved by the General Assembly, ${ }^{67}$ following the Fourth Committee's hearing of petitioners from the territory. On this occasion the conflicts between the Guinean nationalists were clearly shown, since both critics and supporters of the Regime of Autonomy and Spanish policy made their statements. ${ }^{68}$ Whereas the GeneralSecretary of MONALIGE, Atanasio Ndong, condemned the undemocratic character of the situation in the colony and demanded its independence, ${ }^{69}$ Bonifacio Ondó Edú, participating as President of the Governing Council, argued for the legitimacy of the new regime and the necessity for the population to pass through a period of preparation before complete independence. ${ }^{70}$ As was to be expected, anti-colonialists at the UN were more receptive to the independence claim than to the defence of the metropolitan presence.

The international pressures had some effect in 1966, which proved to be a decisive year for

\footnotetext{
${ }^{63}$ Intervention of Jaime de Piniés of Sep. 1963, UN A/AC.109/SR.206.

${ }^{64}$ On Spanish policy towards Gibraltar see Ministerio de Asuntos Exteriores (MAE), Un libro rojo sobre Gibraltar (Madrid, 1965); MAE, Un nuevo libro rojo sobre Gibraltar (Madrid, 1968).

${ }^{65}$ Spanish colonialism in Africa was discussed at the OAU Council of Ministers' meetings from 1966. The Heads of State's meeting approved a resolution on 6 Nov. 1966, CM/82(VII), expressing support for all efforts to secure the unconditional liberation of all African territories under Spanish domination.

${ }^{66}$ UN A/AC.109/99.

${ }^{67}$ General Assembly Resolution 2067(XX) of 16 Dec. 1965, UN A/PV.1398a .

${ }^{68}$ A/6169, Report of Fourth Committee.

${ }^{69}$ Statement of Atanasio Ndong on 16 Nov. 1965, UN A/C.4/659.

${ }^{70}$ Statement of Bonifacio Ondó Edú on 8 Nov. 1965, UN A/C.4/656.
} 
the change of Spanish perception of its colonial presence in Central Africa. During the meetings of the Committee of Twenty-four in Algiers in June, the Spanish ambassador unexpectedly invited the Committee to visit Equatorial Guinea, so that it could verify the actual political situation in the colony for itself. ${ }^{71}$ This was intended to counter the image presented by the Guinean petitioners. ${ }^{72}$ What the Spanish diplomats did not expect was the overwhelming demands for decolonization expressed by the population before the UN sub-committee that was eventually sent to Equatorial Guinea. ${ }^{73}$ In fact, the visit was a stimulus for the nationalist movement, which appeared before the sub-committee with only one demand: that of independence. As was also clear from the meetings held with members of the autonomous administration, the Regime of Autonomy had become discredited in the view of its own officials. Even the Spanish authorities seemed to be changing their discourse in front of the sub-committee, arguing that the Autonomy was only a step towards and a preparatory phase of total independence. It seemed that all groups, the supporters of the separation of the island and mainland included, saw independence as the only option. Disagreements were about the timing of the Spanish withdrawal and the nature of independence. ${ }^{74}$

\section{TOWARDS THE TRANSFER OF POWER:}

\section{THE CONSTITUTIONAL CONFERENCE OF EQUATORIAL GUINEA}

The visit of the Special Committee to Equatorial Guinea precipitated the decolonization process, highlighting the extroverted character of Equatorial Guinea's path to independence. As was to be expected, the final report submitted by the Committee of Twenty-four on November 1966 reasserted the right of the Guinean people to self-determination and independence. It expressed doubts about the legitimacy of, and effective power exercised by, the autonomous administration, and urged the colonial power to organise a fully representative conference to establish the modalities of the transfer of powers and to fix a date, no later than July 1968, for the end of Spanish rule in the territory. ${ }^{75}$ The failure to convince the United Nations of the validity of the Regime of Autonomy and its potential for the self-government of the

\footnotetext{
${ }^{71}$ UN A/AC.109/SR.451.

72 Another of them Daniel G. Mbandemezo'o had been heard by the Committee on 15 June, UN A/AC.109/SR.447.

${ }^{73}$ UN A/AC.109/186, Special Committee Resolution of 21 June 1966.

${ }^{74}$ Report of Subcommittee of Equatorial Guinea, UN A/AC.109/L.348 and A/6300/Rev.1, Chapter IX.
} 
population left the Spanish government without arguments. After the overwhelming expressions in favour of independence made before the international delegation, the metropole's promise that it would grant independence when the population desired it had now to be fulfilled if it wanted to avoid aggravating the internal and international anti-colonial campaign. ${ }^{76}$ All this impelled Franco's government to call the proposed Constitutional Conference to determine the future of Equatorial Guinea. ${ }^{77}$

My argument is that, in the absence of powerful economic or strategic interests, discursive logic predominated. This was clear in the report of a Spanish inter-ministerial commission which met from April to June 1967, that showed that, by that time, the majority of Spanish government departments regarded the sub-Saharan colony as dispensable, and the few existing economic interests as defensible within an independent state. ${ }^{78}$ The only part of government at variance with the plan for independence was the colonial administration: conflict was sustained throughout the whole process of the transfer of power between the Ministry of Presidency and the Foreign Ministry, which had assumed responsibility for the withdrawal. The former sought to keep the Spanish influence and interests in the territory. The later was primarily concerned with the international dimension of decolonization and international opinion in United Nations. In order to fulfil their aims, both ministries supported different Guinean groups and leaders, thereby contributing to the fragmentation of the nationalist movement.

All political groups concerned - both in Madrid and Guinea - were trying to gain the best positions in the new context. Atanasio Ndong, secretary-general of MONALIGE, had returned to Guinea from exile in October $1966 .{ }^{79}$ On the eve of the Conference, despite the non-pluralist character of the Spanish regime, different political groups in Guinea managed to find a range of support from within the metropolitan government, as would be made clear later. Among the

\footnotetext{
${ }^{75}$ Ibidem.

${ }^{76}$ The announcement of this decision, along with the recommendations of the Subcommittee of Equatorial Guinea, were approved by the General Assembly on 20 Dec. 1966, as resolution 2230(XXI), in which it invited Spain to establish full democratic freedoms and to transfer power to the government elected in a general election. It also requested Spain 'to ensure that the Territory accedes to independence as a single political and territorial unity'.

${ }^{77}$ An extraordinary meeting with Franco held in El Pardo on 16 November. Report 'Informe sobre el tema de los territorios españoles en África ante las Naciones Unidas' on 28 Nov. 1966, AMAE R.8786/3; Statement of Jaime de Piniés in the Fourth Committee of 20 Dec. 1966, UN A/C.4/SR.1665.

${ }^{78}$ Interministerial Commission Report, 'Comentario resumen de los informes presentados a la Comisión Interministerial sobre el futuro de Guinea por los Representantes de los diversos Ministerios', Proceedings of the Constitutional Conference of Equatorial Guinea (C.C.E.G) (1967).

${ }^{79}$ Statement of Atanasio Ndong to the Subcommittee of Equatorial Guinea, Report of Subcommittee of Equatorial Guinea, III.C., UN A/AC.109/L.348 and UN A/6.300/Rev.1.
} 
preliminaries, the Asamblea General of Equatorial Guinea established a special committee to carry out an enquiry into the opinions of the different social and political groups regarding changes to the colonial situation. This was probably the most democratic moment of the whole process, where many groups and particulars expressed publicly their opinion; however it would not be taken as the point of departure of the Constitutional Conference. In its conclusions, the cleavage between those in favour of a unitary independence and those from the island of Fernando Po who aimed at separated independence was made clear. ${ }^{80}$ Meanwhile, further pressure was exerted at the United Nations, when representatives of MONALIGE appeared once again before the Special Committee in September 1967, complaining about the delay in the start of the Conference and the support that certain Spanish settlers were giving to the separatist movement based in the island. ${ }^{81}$

Two different questions had to be resolved before the Conference could begin. Firstly, the problem of representation arose from the internal and international disrepute of the autonomous institutions and from the need for all the political groups and social sections to participate, as had been requested in the most recent $\mathrm{UN}$ resolution. The idea of an election to determine the Guinean delegation being discarded by the Francoist regime, the Spanish authorities appointed an extremely large and fragmented delegation, not very inclined to maintain a united position before the Spanish representatives. ${ }^{82}$ The second question was about the aims and nature of the Constitutional Conference itself: the United Nations had not been very explicit about it and the Spanish government vaguely stated that the Constitutional Conference was not a constitutional assembly, its main aims being 'to maintain and to help the dialogue between the Guinean representatives and the Spanish administration'. ${ }^{83}$ Only through the process would this issue be solved.

The Conferencia Constitucional finally opened on 30 October 1967, at the Palace of Santa Cruz, the site of the Foreign Ministry. The first sessions, which lacked a coherent agenda or true dialogue between both delegations, revealed the deep division within the Guinean delegation between the separatist and the unionist parties. On one side there were the majority of the political groups, MONALIGE, MUNGE and IPGE, and most of the members of the Regime of Autonomy. The majority of the Guinean delegation sought the formation of a provisional government to which

\footnotetext{
${ }^{80}$ Statement of Gustavo Watson Bueco, 2nd. meeting Political Commission C.C.E.G., 1967.

${ }^{81} \mathrm{UN}$ A/AC.109/SR.552, Statement of Saturnino Ibongo and Rafael Evita of 6 Sep. 1967.

82 Members of the political institutions of the territory, as well as of the nationalist movements MONALIGE, MUNGE, IPGE and the recent Unión Bubi (Bubi Union) and Unión Democrática (Democratic Union), as well as representatives of 'ethnic minorities', were invited to the Conference. All inall, the Guinean delegation totalled 43. Proceedings C.C.E.G., 1967.

${ }^{83}$ Statement of Ramón Sedó, 2nd plenary meeting C.C.G.E., 1967.
} 
power would be transferred when the Spanish government fixed the date for independence: the drafting of the constitution was to be delayed until after the Spanish withdrawal. ${ }^{84}$ On the other side, the minority in favour of the separation of Fernando Po from the mainland hoped to achieve this aim through the Conference. ${ }^{85}$ This question was one of the major themes of the Conference from start to finish: the debate centred on the political subject to whom the principle of selfdetermination should be applied. On 15 November, after a number of Guinean delegates from the island had threatened to withdraw, the Conference was adjourned. The Spanish government claimed the first phase of the Constitutional Conference to be over, although it did not mention when the Second Phase would begin.

Immediately after that, a group of Guinean delegates from the majority group flew to New York, in order to participate in the meetings of the Fourth Committee, where they expressed their disappointment with the Spanish government and demanded complete independence for the territory before 15 July 1968, respect for its territorial integrity, and the establishment of a provisional government followed by a general election. ${ }^{86}$ The accusations led to the approval of a new resolution on Equatorial Guinea by the General Assembly on 19 December 1967, with clearer aims of the UN with respect to the Constitutional Conference, which, according to the UN, should be reconvened 'in order to work out the modalities of the transfer of power, including the drawing up of an electoral law and of an independence constitution'. 87 The resolution insisted upon the guarantee of democratic freedoms and the transfer of powers to the government with a common mandate. The general elections, which would vote the aforesaid government, would be supervised by the United Nations.

The Special Committee, for its part, devoted many of its sessions in March 1968 to examine the procedure and the aims of the Constitutional Conference of Equatorial Guinea. ${ }^{88}$ Much of the prejudice disclosed by the anti-colonial group referred to the referendum announced by Spain, which was to be held after the Constitutional Conference, since for many delegates the independence of the territory should not be included in the referendum, and was not dependent

\footnotetext{
${ }^{84}$ These demands were advanced in a document signed two days before the start of the Conference, by a large number of delegates, in an obvious attempt to adopt a common stance. Statement of Macías Nguema, 1 st. meeting Political Commission C.C.E.G., 1967.

${ }^{85}$ This group was formed by those members of the autonomous institutions from the island such as Enrique Gori Molubela, as well as the recently founded Unión Bubi, headed by Edmundo Bosío Dioco.

${ }^{86}$ Statement of Antonio Ndong, Francisco Macías, Francisco Salomé Jones, Antonio Eworo Obama, José Loeri Comba, Saturnino Ibongo and Armando Balboa. UN A/C.4/SR.1748.

${ }^{87}$ General Assembly Resolution 2355(XXII).

${ }^{88} \mathrm{UN}$ A/AC.109/SR.579, 582, 583, 587, 588, 589.
} 
upon any consultation of the population. ${ }^{89}$ Guinean petitioners requested the presence of United Nations observers in the process, and denounced the delaying tactics and the encouragement of the separation of the territory by the colonialists within the Spanish government. ${ }^{90}$ The notice of the resumption of the Conference was announced in UN at the end of that month, ${ }^{91}$ thereby avoiding harsher criticism of the resolution that was approved in the Special Committee on 1 April 1968. ${ }^{92}$

The commitment of the Spanish government to the international principles of decolonization was made clear in the statement of the Foreign Minister during the resumption of the Conference on 14 April 1968. ${ }^{93}$ The colony would reach independence as a single political unit later that year and the Conference would prepare an electoral law and a democratic constitution for the new African state, which would be submitted to a referendum of the entire Guinean population. ${ }^{94}$ However, despite the government's desire to settle the disputes over the territorial arrangement, the separatist lobby did not drop its claim for Fernando Po's independence from the mainland.

In addition, another rift developed among those members of the Guinean delegation who favoured territorial unity. During the interim between the two phases of the Conference, the MONALIGE secretary-general, Atanasio Ndong, had become the Foreign Ministry's candidate for the presidency of the new state, ${ }^{95}$ making him and his adherents' allies of the Spanish delegation during the second phase of the Conference. At the same time, a number of delegates from MUNGE, IPGE and MONALIGE, plus the majority of the members of the autonomous institutions had rallied around a former colonial civil servant and vice-president of the Governing Council, Francisco Macías Nguema, under the denomination of Secretariado Conjunto (Joint Secretariat). This group looked for legal and political advice to Antonio García Trevijano, a lawyer

${ }^{89}$ The British delegation was one of the most critical with Spain in this respect, after the censorship received in the same Committee for its policy towards Gibraltar, as results of Spanish lobby in UN. ONU A/AC.109/SR.586. Confidential Telegram n.445 from the UK Mission in New York to Foreign Office of 23 Feb. 1968; Confidential Telegram n.834 from Foreign Office to the UK Mission in New York of 27 Feb. 1968; Confidential Letter from the UK Mission in New York to Central Department in Foreign Office on 'Committee of 24 and Spanish Equatorial Guinea' of 14 March 1968. PRO FCO 25/734.

90 Statements of Saturnino Ibongo and Salomé Jones. One of these 'delaying tactics' was the call of municipal elections in the context of the autonomous regime, that were later cancelled, showing the absence of coordination and the divisions inside the Spanish government. UN A/AC.109/SR.582.

${ }^{91}$ UN A/AC.109/SR.593.

${ }^{92}$ UN A/AC.109/289.

93 Proceedings of the C.C.E.G. Guinea, 1968.

${ }^{94}$ Statement of Spanish Government by Minister Fernando M. Castiella, 1st. meeting Second Phase (SP) C.C.E.G., 1968.

${ }^{95}$ Miguel Herrero de Miñón, Memorias de Estío (Madrid, 1993), 37. 
who claimed to be part of the domestic opposition to the Franco regime. ${ }^{96}$ Meanwhile, the Ministry of Presidency divided its support between Ondó Edú and the separatists of Fernando Po.

The Conference continued therefore, to be characterized by disagreement among the Guinean delegation. The paradox of an authoritarian regime proposing a democratic constitution for its colony was another of the difficulties of the process of decolonization. ${ }^{97}$ The lack of any clear procedure, based on a majority vote or on any other criterion, did not help in settling the disputes. There were basically three different overall proposals, and these proved to be incompatible: a document prepared by two Spanish advisers and the more collaborative members of the Guinean delegation, a draft constitution for the island alone, and a text presented by the Joint Secretariat. The solution to the impasse came with a process suggested by the Spanish delegation, according to which the constitution would be drawn up by a small commission and debated at plenary meetings later on. The commission was composed of members of the Spanish delegation and the most collaborative members among the Guinean delegates.

On 22 June, the commission quite unexpectedly presented a full Constitution, as well as an electoral law that had not been previously discussed, to the plenary session of the Constitutional Conference. ${ }^{98}$ In contrast to the Spanish political system, universal suffrage was guaranteed, along with a range of basic individual rights. It was a document full of balances, between centralism and federalism, between the President and the Assembly. Whatever its faults, it did not seem to be a child of Franco's dictatorship. The text was approved by proclamation and not by individual vote. ${ }^{99}$

Those delegates who had not participated in the drafting process soon denounced the lack of consensus that had been apparent during the conference. In a press conference for the foreign media on 25 June, 15 of them accused the Spanish government of having imposed the constitution

96 Trevijano's was, however, a personal connection and not proof of a wider commitment with the independence of colonial Africa by the opposition forces in Spain, which hardly ever took an interest in colonial questions.

97 This contradiction did not pass unnoticed to many ordinary Spaniards, as was made clear in a number of newspaper articles published in Madrid and Barcelona such as Madrid (2 May 1968). The Spanish government reacted by announcing that all documents relating to the Constitutional Conference were considered to be classified according to the Official Secrets Act.

98 The proposed Constitution was composed of 58 articles, plus 3 transitional and 1 complementary provisions.

99 During the same session, the Spanish government presented a Declaración de Intenciones (Statement of Intentions), according to which it would concede independence to Equatorial Guinea after the population had voted on the proposal in a referendum. However, independence was not considered to be dependent on the popular approval of the Constitution, though no alternative was established in case the Guineans rejected it. All this shows not only the improvised character of the whole process, but also that the Spanish decision to withdraw was firm at that time. 
and the electoral law. ${ }^{100}$ At the same time as the Spanish representative at UN, Jaime de Piniés, revealed that the negotiations had ended, ${ }^{101}$ many Guinean nationalists flew to New York in order to attend the meetings of the Special Committee. The disagreements that had emerged in Madrid were now displayed before the international public. Those around Atanasio Ndong, former petitioner to the UN and one of those who had collaborated with the Spanish government in writing the draft constitution, spoke in defence of the Conference's outcome and Spain's willingness to concede independence. ${ }^{102}$ Meanwhile Macías Nguema's faction denounced the undemocratic procedure by which the constitution had been drafted and imposed upon the Guinean people, asked for the Special Committee to condemn the Conference and demanded presidential elections and the immediate withdrawal of the Spanish authorities. ${ }^{103}$ Even the separatist group, which had never before resorted to the UN where any modification of the colonial borders was seen as contrary to the principles of decolonization, sent a delegation claiming self-determination for Fernando Po. ${ }^{104}$

Contrary to the desire of these latter groups there was little attention paid to the critics, for the Spanish government now seemed definitely committed to its withdrawal from Equatorial Africa. Furthermore, Jaime de Piniés finally announced that independence would be granted on 12 October, and that the referendum on the Constitution would be held in August. ${ }^{105}$ The democratic dimension of the decolonization process appeared somehow unimportant as far as the principle of sovereignty was respected. The UN expressed its support for the Spanish policy in a consensus adopted by the Special Committee on 19 July, that only briefly mentioned the disagreements among the Guinean nationalists in order to encourage the peaceful ending of the process envisaged by Spain. It also announced the participation of the UN during the next steps to independence: a mission was promptly appointed to supervise the referendum and the general elections. ${ }^{106}$

THE TRANSFER OF POWER

\footnotetext{
${ }^{100}$ Le Monde, 26 and 27 June 1968; West Africa, 29 and 6 June 1968.

${ }^{101}$ UN A/AC.109/284/Add.1 (Part I)

102 Statements of Atanasio Ndong and Saturnino Ibongo of 8 July 1968, UN A/AC.109/SR.618.

${ }^{103}$ Statement of Macías of 16 July 1968, UN A/AC.109/SR.621.

${ }^{104}$ Statement of Bosío Dioco y Toichoa Boricó of 17 July 1968, UN A/AC.109/SR.622.

${ }^{105}$ Statement of Jaime de Piniés of 10 July 1968, UN A/AC.109/SR.619.

${ }^{106}$ A/AC.109/SR.635.
} 
The referendum took place in the colony on 11 August $1968 .{ }^{107}$ The nationalist movement appeared at this stage totally divided: whereas people like Ondó Edú and Atanasio Ndong campaigned for the Constitution, the group around Macías Nguema and the island separatists, headed by the planter Edmundo Bosío Dioco, were against it. The Constitutional Conference had provoked a new realignment of the nationalist movement: MONALIGE split between those supporting the Spanish decolonization strategy and those aiming to break with the colonial power. The constitution was finally approved with 72,458 votes, against $40,197 .{ }^{108}$ On Fernando Po, the yes vote won with only 4,763 votes against 4,486 , showing a profound division among the islander population on the issues of independence and the maintenance of territorial integrity.

The preparations and campaign for the general elections for President of the Republic and members of the Assembly started immediately after the referendum. ${ }^{109}$ Several electoral lists were presented, headed by Atanasio Ndong, Macías Nguema, Bonifacio Ondó Edú and Edmundo Bosío Dioco. The elections were held on 22 September, but it was necessary to hold a second round of voting a week later to finally elect the President, as the first results gave an insufficient majority to Macías Nguema over Ondó Edú, while Atanasio Ndong and Bosío Dioco were dropped in the first round. Finally, on 3 October, Macías Nguema was proclaimed first president of the Republic of Equatorial Guinea, after winning the elections with the late support of Ndong and Dioco. ${ }^{110}$ The UN mission certified that the elections had been free and democratic. ${ }^{111}$

It had been the candidate without any sort of official support, Macías Nguema, who won the vote of the majority of the population. The Spanish government had divided its preferences between Ondó Edú, Bosío Dioco and Atanasio Ndong, and none of them managed to convince the majority of Guineans of his genuine autonomy from the metropolitan power. Macías, old colonial civil servant, had gained the support of the youngest and the less favoured by the political arrangement of the Autonomy thanks to a radicalised language and the electoral resources he had as vice-president of the autonomous government.

The first independent government of Equatorial Guinea was formed by a coalition of the

${ }^{107}$ UN. A/7200/Rev.1, Report of Special Committee of Twenty-four containing a descriptive account of the activities of the United Nations Mission for the Supervision of Referendum and Elections in Equatorial Guinea.

${ }^{108}$ Decreto (Decree) 2070/68, of 16 August 1968.

109 Some census amendments proposed by the United Nations mission added a further 14,000 voters to the electoral roll. UN. A/7200/Rev.1.

${ }^{110}$ The results of the first round were: Macías Nguema 36,716, Ondó Edú 31,941, Atanasio Ndong 18,223, and Bosío Dioco 4,795. UN. A/7200/Rev.1.

${ }^{111}$ UN. A/7200/Rev.1. 
main political groups, excluding the former President of the autonomous Governing Council, Ondó Edú. The ceremony transferring power was concluded, as announced, on 12 October 1968 in Santa Isabel, when the Information and Tourist Minister, Manuel Fraga Iribarne, handed over sovereignty on behalf of the Spanish government to Macías as the representative of the Guinean people. ${ }^{12}$ The previous day, the General Assembly had adopted a new consensus expressing its appreciation to the Spanish government and congratulating the people of the territory on their independence. ${ }^{113}$ The following month, the new sovereign state of Equatorial Guinea was admitted the United Nations. ${ }^{114}$

Within six months, the relationship between the old colonial power and the new African state had almost completely broken down and the majority of the Spanish settlers had fled the country. An attempted coup d'etat by the Foreign Minister and old nationalist, Atanasio Ndong, with some measure of unofficial support in Madrid, was used by President Macías Nguema to justify the revocation of the Constitution and the settlement of a regime of terror in Equatorial Guinea. In Spain Fernando M. Castiella's departure from the Foreign Ministry meant the end of the policy of decolonization and the predominance of the hard-line stance of the Minister of Presidency: the decolonization of Spanish Sahara had to wait until the end of the Franco regime.

\section{CONCLUSION}

The independence of Equatorial Guinea is an extreme example of the relevance of the international factor in African decolonization, and particularly of the transformation of international norms promoted by the anti-colonial group of states at the United Nations. The international body played several roles in this process. It provided one of the arenas in which the nationalist movements and Spanish officials met and reached agreement. The nationalist movement resorted to the international arena in a strategy of extraversion, in order to overcome its internal weakness and the colonial rigidity. For its part, the Franco regime, in

112 There exists a film documentary on the transfer of power in Noticiario Español, NODO, n.1346-A, of 21 Oct. 1968. See also Juan Durán-Lóriga, Memorias diplomáticas (Madrid, 1999) 122-123.

${ }^{113}$ Report of Fourth Committee, UN A/7265 par.5.

114 This was on 12 November 1968; Saturnino Ibongo was the first representative of Equatorial Guinea at UN. Request for Admission by the President of the Republique of Equatorial Guinea, UN A/7306; Resolution of Security Council 260/1968, UN A/7310; General Assembly Meeting UN A/PV.1714. Saturnino Ibongo was the first representative of Equatorial Guinea at the UN. 
spite of its dictatorial and centralist character, transformed its colonial policy in Central Africa into one of withdrawal and decolonization due to its desire to participate fully in an international society recently transformed by the fall of the main colonial empires.

The UN also offered the language with which the actors on both sides were able to settle the late-colonial conflict. Only those Guineans who used the international language of independence and territorial integrity had a chance to negotiate with and replace the Spanish administration in the territory. ${ }^{115}$ Thus, the idea of the self-determination of colonial people was not only an instrument in the hands of the anti-colonial groups, but it also defined the outcome of the confrontation with the colonial power. In this sense, decolonization would mean statehood and the end of the Spanish colonial rule would give rise to the appearance of the sovereign state of Equatorial Guinea, whose territory and administrative apparatus were those of the old colony. ${ }^{116}$

During decolonization, the democratic dimension of the principle of self-determination, linked to the idea of government by consent, was often superseded by its external dimension namely, independence from European rule and the international recognition of the former colony as a sovereign state. In this sense, there was no place for questioning either the territorial arrangement of the old colony, or statehood as the solution to the end of European rule. ${ }^{117}$ This was clear in the case of Equatorial Guinean, where any argument for a different outcome to unitary independence, such as the separation of the colony or its integration with Cameroon, was set aside without any real debate among the population. Unitary independence was considered at that time as the most progressive path, facing the more regressive policies of the settlers' interests or more conservative groups in the colony. However, it testifies to the fact that Spanish officials were more concerned about international opinion than about carrying out a democratic process of withdrawal.

115 The strength of the nationalist project, vis à vis other options for the colonial conflict, is well stated by Frederick Cooper: 'The nation was not the only unit that people imagined, and the predominance of the nation-state in post-1960 Africa resulted not from the exclusive focus of African imaginations on the nation but from the fact that the nation was imaginable to colonial rulers as well'. F. Cooper, 'Conflict and Connection: Rethinking Colonial African History’, The American Historical Review, 99: 5 (Dec.1994), 1537.

116 It is important, here, to emphasise the relevance of the normative and discursive dimension of the decolonization process, in a related way though not exactly with the same argument as Robert H. Jackson when he stated: 'Decolonisation was above all an international change of ideas about legitimate and illegitimate rule'. I am not conceiving of the international norms on self-determination as a force that in its own right pressed the colonial powers to withdraw, but rather as a language available to the anti-colonial movements that is not separate from the use that actors make of them. Robert H. Jackson, 'The weight of Ideas in Decolonisation: Normative Change in International Relations' in Judith Goldstein \& Robert O. Keohane (eds.), Ideas and Foreign Policy. Beliefs, Institutions and Political Change, Cornell University Press, Ithaca \& London, 1993, p.130.

${ }^{117}$ James Mayall, 'Self-determination and the OAU' in I.M. Lewis, Nationalism and Self Determination in the Horn of Africa (London, 1983), 77-92; J. Mayall, Nationalism and International Society (Cambridge, 1990). 
The externalisation of the process explains in part its contradictions and difficulties. First, there was the paradox of a dictatorial regime, such as Franco's, drafting a democratic constitution to its former colony: the lack of democratic culture led to the incongruities of the whole Constitutional Conference. Secondly, it was not until Guinean nationalists appeared before the United Nations that anti-colonial pressures became more pervasive to Spain. The delay in the decolonization of Equatorial Guinea, in comparison with other African colonies, can be explained in terms of the timing of nationalist demands as well as in terms of Spanish reluctance to decolonize. Finally, the external design turned out rather weak: the lack of consensus among the different nationalist groups in the territory and the inherited political culture from the colony explains the failure of the democratic scheme. In the end, the postcolonial reality proved to be more complex and less manageable than the Spanish officials and international policy-makers had believed. The victory and later regime of terror of Macías Nguema demonstrated both the autonomy of the colonial society as well as the colonial continuities in the new independent state. 